\title{
Waiting for Godot: A Marxist Study
}

\author{
Javed Akhter, Khair Muhammad, Naila Naz \\ Department of English Literature and Linguistics, University of Balochistan Quetta, Balochistan, Pakistan
}

Email address:

sangatjavedakhtar@gmail.com (J. Akhter),khairafroz@gmail.com (K. Muhammad), nailanaz005@gmail.com (N. Naz)

\section{To cite this article:}

Javed Akhter, Khair Muhammad, Naila Naz. Waiting for Godot: A Marxist Study. International Journal of Literature and Arts. Vol. 3, No. 4, 2015, pp. 42-48. doi: 10.11648/j.ijla.20150304.12

\begin{abstract}
This study tends to focus on the different facets and meanings of "Waiting for Godot" by Samuel Beckett. The different occurrences of conflicting and contradictory meanings within the text of the play show existence of the late modernist bourgeois ideology. Based on the theoretical concern of the discussions of Post-Structuralist Marxist theorists Louis Althusser and Pierre Macherey, the main concern of the discussion concentrates on the theory of decentred or disparate text, expounded by Pierre Macherey in his book, "A Theory of Literary Production" (1978). This paper asks how the significant gaps, silences, absences and non-saids in the text of "Waiting for Godot" reflect the presence of the late modernist bourgeois ideology. This paper aims to reflect on the significance of ideology to articulate Post-Structuralist Marxist theory of decentred or disparate text. To make vocal the non-saids of Samuel Beckett's text, the theory and methodology, I seek in this research paper is PostStructuralist Althusserian Hermeneutics that helps to find conflict, disparity and contradiction of meaning within the text and between the text and its ideological content. It also helps to make speak and vocal the silences and non-saids of the play with conceptual framework of Post-Structuralist Althusserian theory of decentred or disparate text. The study would analyse how the ideological processes keep the author silent at certain stages in trying to tell the truth in his own way. It is hoped that this paper would enable the readers and students of literature to theoretical reading of the literary texts, making vocal the unspoken portions of them. They are also expected to find different, conflicting and contradictory meanings within the text of "Waiting for Godot" and between the text and its ideological content.
\end{abstract}

Keywords: Post-Structuralist Althusserism, the Late Modernist Bourgeois Ideology, Text,

Disparity and Contradiction of Meanings, Themes of Existentialism

\section{Introduction}

Before critical analyses of the text of the play "Waiting for Godot", it would be necessary to cast an introductory glance at the play. Samuel Beckett, the most eminent Irish playwright wrote "Waiting for Godot" in French in 1949 and then translated it into English in 1954. This play has been performed as a drama of the absurd with astonishing success in Europe, America and the rest of the world in post second world war era. For this reason, Martin Esslin calls it, "One of the successes of the post-war theatre" (Esslin, Martin, 1980, p.3). In this play, the two tramps, Vladimir and Estragon, who wait expectantly to see Godot near a stunted tree in the middle of nowhere. They do not even know his name, whether he promises to come and visit them, or if, in fact, he actually exists. However, they are still waiting and waiting for him.

The slave-owning Pozzo, his subservient slave, Lucky and the boy, whose name is not mentioned in the play, interrupt their waiting. Godot has nothing significant to do with their lives. They do every possible thing; even intend to commit suicide, just to keep the dreadful silence. The play begins with waiting for Godot and ends with waiting for Godot. Play does not end formally, when the boy, who is as well messenger of Godot, tells the fact to the tramps that Godot is not expected to come this evening.

When we study Samuel Beckett's play "Waiting for Godot", we find it closely tied to bourgeois ideology of the late modernism, not so much, by what it says as by what it does not say. That is why; its text is accompanied with significant gaps, absences, and silences and non-saids. Therefore, its text is ideologically forbidden to say in trying to tell the truth in its own way. In this regard, it is incomplete, decentred and disparate text. It displays conflict and contradiction of meanings rather than unity between meanings. There is no central essence to it but it is just a continuous conflict and contradiction of meanings in the text. There are scattered, dispersed, diverse and irregular 
meanings within the text. It does not mean that there is a piece missing in the text of "Waiting for Godot" to fill in. However, its incompletion is due to the presence of the late modernist bourgeois ideology, which silences it at certain points to reveal the truth. This paper attempts to seek out the principle of its conflict and contradiction of meanings as well as to display how the text's relations to the late modernist bourgeois ideology produce conflict and contradiction of its meanings.

The occurrence of gaps, silences absences and non-saids in the literary text of Samuel Beckett's play "Waiting for Godot" is closely tied to the late modernist bourgeois ideology, which leads to conflict, difference and contradiction of meanings and continuous indication of incompletion of the text that at the end is immanently discernible through nonsaids of the text. However, the play has ahistorical prospect, predisposition towards the perception of absurdity, uncertainty and futility of waiting and nihilism of human existence. It evinces a numerous signs of binary oppositions and most important of all the violation of the conventional drama and direction of expressionism, surrealism, existentialism, stream of consciousness technique and symbolic and allegorical illustration of the dramatic movement of the Theatre of the Absurd. With this pessimist utterance "Nothing to be done" (Beckett Samuel, 1956, p.9), Samuel Beckett introduces the absurd world of "Waiting for Godot," which is a confusion that is shrouded in the enigma of the late modernist bourgeois ideology.

\section{Literature Review}

"Waiting for Godot" is a masterpiece in world literature for its multifarious thematic variety and diversity of meanings. For this reason, it has aroused the great amount of controversial debates and critical discussions among the literary critics and theorists of the world. Therefore, there are so many books and dissertations composed on the works of Samuel Beckett, especially on "Waiting for Godot". Harold Bloom edited a book entitled "Samuel Beckett: Modern Critical Views" (1985), which is an important criticism nearly on all the important works of Samuel Beckett, including "Waiting for Godot". The book consists of various critical commentaries and theoretical interpretations by different scholars on the author and the play under analysis, from different angles. Ruby Cohn edited a book entitled "Beckett: Waiting for Godot" (1987), which also presents different critical commentaries by different critics on "Waiting for Godot", from different angles.

Martin Esslin edited a book entitled "An Anatomy of Drama" (1976), which is a thought provoking book. He also edited another book, entitled "Samuel Beckett: Twentieth Century Views" (1980), which consists of various views on the author under discussion, relating him to the 'Theatre of the Absurd' and philosophy of existentialism. William S. Haney in his essay, "Beckett out of His Mind: The Theatre of the Absurd" states that Samuel Beckett crosses "the linguistic and cultural boundaries by dispensing with narrative sequence, character development and psychology in conventional sense" (Haney, William S. 2001, p.40). He further states that, Samuel Beckett goes beyond "the psychic structures that select, organize, interpret, and limit our knowledge about the world around us" (Haney, William S. 2001, p.42). Gabriele Schwab also believes that Samuel Beckett's plays go beyond the "boundaries of our consciousness in two directions toward the unconscious and toward self-reflection" (Schwab, Gabriele, 1992, 97). Elin Diamond wrote his research paper entitled "Re: Blau, Butter, Beckett and the Politics of Seeing" (2000), which is a political and ideological study of Samuel Beckett.

Abhinaba Chatterjee wrote a research paper entitled “Camus' Absurdity in Beckett's Plays: Waiting for Godot and Krapp's Last Tape" (2013), which is very important analysis of the two dramatic texts of Samuel Beckett, from an existentialist point of view. Darsha Jani wrote a research paper entitled "Futility, Hopelessness and Meaninglessness: Central Forces Leading towards Absurdity in Beckett's Waiting for Godot" (2013), which is also an existentialist study of the play. Komal Rakwal wrote a research paper entitled "Today's Fear of Being in Samuel Beckett's Waiting for Godot" in which she explores existentialist themes in the text.

Fereshteh Vaziri Nasab Kermany in her PhD dissertation "A Study of the Dramatic Works of Samuel Beckett, Tom Stoppard and Caryl Churchill" (2008) has given a general deconstructive look at the text of the play, discussing it along with the plays of Tom Stoppard and Caryl Churchill. This dissertation tried to prove the overall deconstructive mood of Delogocentrism of the play. Noorbakhsh Hooti wrote a research paper entitled Samuel Beckett's "Waiting for Godot: A Post-modernist study" (2011), which is a Post-Modernist analysis of the text. Azmi Azam wrote a research paper entitled Samuel Beckett's "Waiting for Godot: A PostModern Perspective" (2014), in which she discussed the play in Post-Modern fashion. Javed Akhtar wrote a paper entitled "Waiting for Godot: A Deconstructive Study" (2015) in which he presented a Derridean deconstructive analysis of the text of the play.

In short, these books and research papers on the play under discussion are very interesting, informative and thought provoking on the subject in many respects but no one applied Post-Structuralist Althusserian Hermeneutics to it. The present study would be an analysis from a new and innovative perspective on Waiting for Godot, applying PostStructuralist Althusserian Hermeneutics to the text of the given play.

\section{Post-Structuralist Althusserian Hermeneutics}

Post-Structuralist Althusserian Hermeneutics starts with Louis Althusser's rediscovery and restudy of Scientific Marx and rejection of early humanist Marx. Louis Althusser was the most eminent French philosopher, who advanced a theory 
of different levels: economic, political and ideological levels of the social formation. According to him, these levels possess no overall unity, coherent whole and central structural. They are linked with one another but have relative autonomy. At a certain stage of historical development, one level may be dominant. That level may either be determined (in the last instance) by the economic level, or it may be free of it as well. Hence, it is relative.

Louis Althusser also challenged all Hegelian and neoHegelian versions of classical Marxism, which centred on the centred whole, constructed structure or centralized totality. In this manner, he adjusted Marxism in the Post-Structuralist scholarship in the second half of the $20^{\text {th }}$ century. Louis Althusser also advanced literary theory in his essays: "The Piccolo Teatro": Bertolazzi and Brecht (1960), A Letter on Art in reply To Andre Daspre" (1966) and "Cremonini, Painter of the Abstract"(1966). His literary theory differs from those of classical Marxist literary theorists. For him, great literary works do not express any ideology and they do not provide a conceptual understanding of reality. He sees literature as an ideological form and one of ideological state apparatuses. He attempts to show (with the help of Jacques Lacan's Psychoanalysis theory) how ideology functions in the social formation. He puts as follows:

"What art makes us see, and therefore, gives us in the form of 'seeing'; 'perceiving' and 'feeling' (which is not the form of knowing), is the ideology from which it born, in which it bathes, from which it detaches itself as art, and to which it alludes" (Althusser, Louis, 1971, p. 222).

Pierre Macherey, a pupil of Louis Althusser, developed Althusser's theory of literature in detail and advanced a theory of decentred or disparate text in his book, "A Theory of Literary Production" (1978). He sees a literary text by virtue of its form, its fiction distances itself from its ideology, and non-saids, not only conceals but also exposes ideological contradictions. Because such non-said portions of the texts are suppressions, so to speak, within the text of its own 'unconscious'. He puts it, 'There is a conflict within the text between the text and its ideological content" (Macherey, Pierre, 1978, p. 124).

Pierre Macherey rejects neo-Hegelian Marxist literary theory and criticism of Hegelian and neo-Hegelian Marxist literary critics such as Georg Lukacs and Lucien Goldmann. According to him in the unspoken portions of the text, the presence of ideology can be most clearly felt. Furthermore, the text is ideologically forbidden to say certain things in trying to tell the truth. The author finds himself compelled to expose the limits of the ideology in which he writes to reveal its gaps, silences, disparities, absences and non-saids, what is unable to articulate.

Therefore, according to Pierre Macherey the text is always incomplete or disparate. Far from constituting a coherent whole, unity or a centralised structure, it reveals disparity, conflict, difference and contradiction of meanings. For this reason, a literary text is always decentred or disparate. There is no central essence to it, just a continuous conflict and disparity of meanings, which may be seen as scattered, dispersed, and irregular meanings. These are epithets, which Pierre Macherey uses to express his theory of the decentred literary text.

\section{Marxist Analysis of Waiting for Godot}

"Waiting for Godot" is an existentialist play. It presents many themes of existentialism, which is ideology of the late modernist bourgeoisie. Therefore, we fund in the text of the play many themes of existentialism such as absurdity, nothingness, futility, uncertainty, nihilism, thoroughness into being, angst (anxiety) and disappearance of solutions on the part of human beings, who are in turn left exploited, suffered and bewildered by powerful forces of the bourgeoisie prevalent in the social formation. The most characteristic and important literary movement of modern age, beginning in the late thirties with Albert Camus and Henry Miller, is the Theatre of the Absurd and the most characteristic protagonist of the movement is Samuel Beckett. The movement has its close affinities with existentialist philosophy and its theme of absurdity.

Absurdity is one of the main themes of existentialism as well as of the Theatre of the Absurd movement. However, "Waiting for Godot" belongs to this movement. Therefore, its main theme is also absurdity. The play describes existentialist philosophy and its absurdity. It possesses overall feeling of absurdity while simultaneously expresses many other themes of existentialism. Absurd is in fact an existentialist term, which describes existence-a world without inherent meaning of truth. The term absurd can be traced back to Albert Camus' book, "The Myth of Sisyphus." Then Albert Einstein uses the term as follows:

"If at first an idea is not absurd, there is no hope for it" (Arianrhod, Robyn, 2003).

Martin Esslin coined the term the Theatre of the Absurd and used it as the title of his book "The Theatre of the Absurd". He defines the term absurd as follows:

"The meaning of the term absurd is out of harmony with reason or propriety; incongruous.....illogical" (Esslin, Martin, 1964, p. 20).

There are certain things in "Waiting for Godot", which clearly describe absurdity of human existence and the world. The two tramps Estragon and Vladimir wait for Godot, whom they do not know and they claim to be acquaintance with him but in fact, they hardly know him. They also admit that they will not recognize him when they see him. At the opening scene of the play, Estragon is struggling to remove his boots from his feet. He gives up, uttering these words:

"Nothing to be done" Vladimir says (advancing with short, stiff strides, legs with apart) I'm beginning to come round to that opinion. All my life I've tried to put it from me, saying Vladimir, be reasonable, you haven't yet tried everything. And I resumed the struggle. (He broods, musing on the struggle. (Turning to Estragon) So there you are again" (Beckett, Samuel, 1956, Act One, p. 9).

The sense of absurdity makes the tramps incapable of doing anything. Therefore, they cannot do anything. They 
intend to commit suicide but fail to do so due to their inactiveness and passivity to any action. When Estragon's pants fall down, he does not notice them until Vladimir tells him to pull them up. The utterance "nothing to be done," (Beckett, Samuel, Act1, p. 42) is occurred repeatedly in most of their dialogues, which express the absurdity in human life.

The notion of the absurd is commonly considered as equal to that of meaningless. But the equation, the Absurd= meaningless is dubious from the beginning in Jean-Paul Sartre's novel "Nausea", when Roquentin discovers the absurdity of the object-in-itself, this discovery engenders a series of dynamic reactions that could not conceivably proceed from a purely negative notion such as meaninglessness. For this reason, the question is wrong: the absurd does not necessarily equal to the meaninglessness but it may be in itself meaningful proposition. The greatest part of Samuel Beckett's drama is directly concerned with absurdity and meaninglessness in one domain or another of human experience. In fact, the notion of absurdity differs from that of meaningless, when Pozzo says as follows:

"Pozzo: (suddenly furious) Have you not done tormenting me with your accursed time! It's abominable! When! When! One day is that not enough for you, one day he went dumb, one day I went blind, one day we'll go deaf, one day we were born, one day we shall die, the same day, the same second, is that not enough for you? (Calmer.) They give birth astride of a grave, the light gleams an instant, then it is night once more. (He jerks the rope.) On!" (Beckett, Samuel, 1956, Act Two, p. 93).

In the last scene of the play, the defeat of meaningful is symbolized by the dejection of Godot's not coming. It is the most striking example that reflects obliteration in total despair and angst of the characters Estragon and Vladimir, which are most fully embody the normal human aspirations towards significance. When Estragon and Vladimir are revealed that Godot is not coming this morning, they intend to commit suicide, expressing their despair and angst, which is pervasive throughout the play.

The utterances: 'nothing to be done', 'there's nothing to do' (Beckett, Samuel, 1956, Act One, p.74) and 'the essential doesn't change' (Beckett, Samuel, 1956, Act One, p. 21) depict futility and absurdity of human life in the capitalist social formation, revealing the late modernist bourgeois ideology. That is the final absurdity in Samuel Beckett's world: that, at the same time as the existentialist have concluded that the ultimate 'self' is nothingness, which can only 'become' or achieve the slightest semblance of meaning through acts and words, the scientists have suggested that all acts are meaningless, in the context of a meaningless time and space.

While, the philosophers, the logical positivists and others have shown that however, intriguing languages may be considered as pure sound, it also is fundamentally meaningless and arbitrary when considered as a means to the knowledge of reality. Moreover, if the meaninglessness of acts as such is not a primary theme in Samuel Beckett's play, the meaninglessness of language is very basic material of which his drama is made of, from the opening utterances to the closing utterances of "Waiting for Godot". As a result, the play presents disparity between words and action of the characters. We find complete disparity between the characters' words and deeds. For example, Estragon and Vladimir think to commit suicide, but they fail to do so because of their incapability of any action.

"Vladimir: We will hang ourselves tomorrow.

Unless Godot come.

Estragon: And if he comes?

Vladimir: We will be saved" (Beckett, Samuel, 1956, Act Two, p. 94).

We can mostly notice their incapability to do anything through the play.

"Estragon: "Why don't we hang ourselves?

Vladimir: With what?

Estragon: you haven't got a bit of rope?

Vladimir: No.

Estragon: Then we can't.

Vladimir: Let's go.

Estragon: Oh wait, there is my belt.

Vladimir: It's too short.

Estragon: You could hang on to my legs.

Vladimir: And who would hang onto mine?

Estragon: True" (Beckett, Samuel, 1956, Act Two, p.93).

Similarly, we may notice the disparity between words and incapability of any action of the characters throughout the play. They intend to do something but cannot do anything in the whole play. They inertly wait for Godot instead of finding him out. By the end of the play, they want to go but they cannot move.

"Vladimir: Well, shall we go?

Estragon: Yes, let's go.

They do not move" (Beckett, Samuel, 1956, Act Two, p. 94).

Rene Descartes made philosophical proposition: "cogito ergo sum" ('I think, therefore I am'). In the words of JeanPaul Sartre, "existence precedes essence." For Samuel Beckett to speak is to exist. Vladimir and Estragon act if one realizes that the words themselves are meaningless, and consequently, that existence, which they create, is meaningless. Samuel Beckett is following a lonely trail of paradoxes in his search for the ultimate silence of the selftranscending both acts and language, which shall be the starting point of new existence and rebirth beyond the limits of time and space. Existentialist philosophers are not expected any change in human situation. As Albert Camus states: "The more things change, the more they are the same". This is also a theme of "Waiting for Godot". For example;

"Estragon: Noting happens, nobody comes, nobody goes, it's awful" (Beckett, Samuel, 1956, Act One, p. 41).

The loss of identity or misrecognition of human beings is an important theme of existentialism. "Waiting for Godot" depicts the loss of human identity or misrecognition of human beings in the capitalist social formation, expressing the late modernist bourgeois ideology. Vladimir and Estragon are identified by the nicknames as Didi and Gogo. The boy, 
messenger calls Vladimir as Mr. Albert. In fact, these characters have no personality, they scarcely exists as characters, save in their words. In addition, if their words are meaningless at the centre of themselves, is additionally meaningless even in their pretences at existence. "The characters hardly have any individuality and often even lack a name; completely, halfway through the action they tend to change their nature completely. Pozzo and Lucky in Beckett's "Waiting for Godot", for example, appear as master and slave at one moment only to return after a while with their respective positions mysteriously reversed" (Esslin, Martin, 1960, p.3).

The most important existentialist theme of the play is Kierkegaardian view of throwness into being in infinite universe. Pozzo shows his awareness of this existentialist conviction. Gradually the warm radiance of eternity, which comforted our forefathers is giving place to a relentless awareness of infinite cold and infinite silence (this is one of the themes of Lucky's famous speech in Waiting for Godot), an ultimate, unspeakable, inconceivable absolute of nonmeaning, against which we would defend ourselves with what?, a little tickling rampart of clocks! Jean-Paul Sartre concludes it 'a nothing at the centre of the self'. Moreover, Wittgenstein says, "Where there are no words, there is no silence". Vladimir and Estragon signify a profound misunderstanding, absurdity, and uncertainty of waiting.

"Waiting for Godot" is not in fact a logo-centred text, possessing fixed, centred and unified meanings but it is disparate, de-logo-centred or decentred text. It reveals conflicting, disparate and contradictory meanings within the text and between the text and its ideological content. However, Samuel Beckett tries to create a logo in the symbol of Godot for whom the tramps wait. However, Godot does not make his appearance in the play. Nevertheless, many critics are still hopeful of his coming. As Terry Eagleton says, "Godot's absence may have plunged everything into ambiguity, but that must logically mean that there is no assurance that he will not come" (Eagleton, Terry, 2003, p. 67).

Who or what Godot stands for? This question has been insoluble from beginning to the end in the play and still is an enigma in literary academia. The critics make different interpretations of the logo-centred Godot in a variety of ways. Some critics suggest the meaning of God as inaccessible Godot. On the contrary, some other critics interpret it death, some kind of future utopia, revolution and national liberation. Samuel Beckett did never explain the term. When the director Alan Schneider asked Samuel Beckett, who is Godot? Samuel Beckett answered," If I knew I'd have said so in the play" (Bair, Deirdre, 1993, p. 382).

Catherine Belsey said that ideology is engraved in each and every utterance and use of language but there are some other signifying systems of the social formation also where its presence can be traced easily: common sense, everyday behaviours mores and folkways, myths, social gestures and routine truisms are relevant signs in this regard (Belsey, Catherine, 1980, pp.56-85). The following dialogues between
Vladimir and Estragon reflect the use of the sign of doubt, which is ideological construct. This reflects the presence of the late modernist bourgeois ideology in the text of the play, which is evident in the following dialogues:

Vladimir: "Did you ever read the Bible?

Estragon: The Bible... (He reflects.) I must have taken a look at it.

Vladimir: Do you remember the Gospels?

Estragon: I remember the maps of the Holy Land. Coloured they were. Very pretty. The Dead Sea was pale blue. The very look of it made me thirsty. That's where we'll go, I used to say, that's where we'll go for honeymoon. We'll swim. We'll be happy.

Vladimir: Ah yes, the two thieves. Do you remember the story?

Estragon: No.

Vladimir: Shall I tell it to you?

Estragon: No.

Vladimir: It'll pass the time. (Pause.)Two thieves, crucified at the same time as our saviour. One.

Estragon: Out what?

Vladimir: Our saviour. Two thieves. One is supposed to have been saved and the other... (he searches for the contrary of saved).... Damned.

Estragon: Saved from what?

Vladimir: Hell.

"One of thieves was saved" (Beckett, Samuel, 1956, Act One, p.12).

The late modernist bourgeois ideology shattered the religious beliefs of modern man. In the feudal era, religion was an ideological state apparatus and signifying practice, which played its significant role to recruit the subjects in a specific power apparatus of social formation, and at the same time, it strengthened the other powerful ideological signifying practices. In modern era of capitalism, religion as an ideology of feudalism was replaced by doubt, reason, and Godless ideology.

The complex dramatic structure of "Waiting for Godot" is based upon symbols and ideological content, which reveals in existential terms of angst, fear of freedom and absurdity of human existence. Existential absurdity of human existence is one of the ideological basics of the text. The vertical repression and layering or sedimentation is dominant structure of the text of the play. Existential myth about the meaning of life and absurdity of human existence is ideological context of the play. The late modernist bourgeois ideology is itself an ideological expression of capitalism and its reification of daily life, which is to be found in "Waiting for Godot" in the increasing fragmentation of capitalist socio-cultural ethos. In this way, it shows many themes of existentialism of which absurdity and futility evidently found their source in Nietzschean nihilism, what kinds of things are possible if God is dead.

At the same time the text's bleak references to one of the most important socio-political themes in depiction of MasterSlave relationships between Pozzo and Lucky, shed light on class relations between the exploiting and exploited classes 
and nations in the modern capitalist world. As Fredric Jameson interprets the play:

"The Beckett's play, involves not one but two pseudocouples, the relatively egalitarian team of the two clochards, (differentiated only by their physical ailments),being episodically juxtaposed with a very different and decidedly unegalitarian pair in the person of Pozzo-the master, presumably signifying England and Lucky the slave, presumably signifying Ireland and its intellectuals"(Jameson, Fredric, 2007, p. 364).

Samuel Beckett uses the symbol of Godot in the play, to portray human situation in modern capitalist social formation and this conflict comes to a head in the meaning of Godot, in which the text of the play is ambiguously torn between contradictory meanings. In this way, "Waiting for Godot" becomes an ambiguous play and ideological basis of this ambiguity is that the play reveals human suffering, exploitation and oppressive effects of modern capitalism on human beings; and at the same time it suggests a reflexive practice of distrust that any action to change the modern capitalist social formation is futile and absurd. It celebrates at the same time that industrial capitalism has victimized human beings, who have become exploited, suffered, inhuman, bewildered and threatened by powerful exploiting forces of the bourgeoisie. Finally, the play tries to make us believe that any action to change the prevailing modern capitalist system is futile, absurd and impossible.

The principle of the text of this play's conflict of meanings, we have to analyse, is its complex relationships to the late modernist bourgeois ideology. In this regard, there is coexistence of two kinds of utterances in the text of the play, the ideological utterances and the other are fictional utterances, which is typical of the text and is the juncture that is distinct, and an ideology, which is confused, making the work literary piece of art. As Terry Eagleton remarks, 'Beckett's refusal of such daunting high-toned words as tragedy "Waiting for Godot" is described as a tragic-comedy belongs with an under-dog suspicion of ideology" (Terry, Eagleton, 2003, p. 66).

In this manner, we may claim that Samuel Beckett has clearly shown in the play that "...one cannot isolate ideological utterances and consider them as independent realities, as enclave: ideology is so caught in the tissue of the work that it there take on a new status, its immediate nature is transformed. One could say, to take up a vocabulary already familiar: from the illusion that it was, it becomes fictive" (Pierre, Macherey, 1978 P.297).

\section{Conclusion}

In an effort to look for the signification of contradiction within the text of the play "Waiting for Godot" by Samuel Beckett and its complex relationship to the late modernist bourgeois ideology, one can actually make a choice to unfold vigour theoretical energies of Post-Structuralist Marxist Althusserian theory of decentred text. The research based upon Post-Structuralist Marxist reading of the short play
"Waiting for Godot" is new, innovative and useful interpretation for readers and scholars on Samuel Beckett in many respects. The study analysed that the text's conflict and disparity of its meanings reveals its unspoken portions that the late modernist bourgeois ideology has suppressed. As a result, the difference, conflict and contradiction of text's final meanings are flux, contradictions, silences, absences and unspoken portions of the text, which show its complex relationship to the late modernist bourgeois ideology.

The present paper concludes that the play presents an essential characteristic of human situation, which emphasizes suffering, absurdity, futility, angst and nothingness of human existence. The play also shows class relations in depiction of Master-slaves relationship between Pozzo and Lucky, which is a bleak reference to the exploiting and exploited classes and nations in the modern capitalist world. At the same time the play makes us believe that people wait something, which does not materialize in the modern capitalist social formulation, just as expected Godot does not appear in the play.

Still there are many other untapped and unexplored areas of the play; binary oppositions (which is one of the most important themes of Post-structuralism and Post-modernism) between Vladimir and Estragon's actions, personalities and ways of thinking and behaving is one of the examples. The present study may prove useful and helpful to suggest clues to the unexplored and untapped areas of the play for future research scholars.

\section{References}

[1] Akhter, Javed. (2015) Waiting for Godot: A Deconstructive Study. International Journal of Humanities and Cultural Studies. ISSN 2356-5926, Vol. 2, Issue 1, June 2015, pp.42-63.

[2] Althusser, Louis. (1969). For Marx. Paris, France: The Penguin Press.

[3] Althusser, Louis. (1971). Lenin and Philosophy and Other Essays. Trans. Ben Brewster. London, Great Britain: New Left Books.

[4] Arianrhod, Robyn. (2003). Einstein's Heroes: Imagining the World through Language of Mathematics. Australia: University of Queensland Press.

[5] Azam, Azmi. (2014), Samuel Beckett's Waiting for Godot: A Post-modern Perspective. International Journal of English and Education. ISSN: 2278-4012, Volume: 3, Issue 2, April 2014, pp. 504-507.

[6] Bair, Deirdre. (1993). Samuel Beckett: A Biography. New York: Simon and Schuster.

[7] Becket, Samuel. (1956). Waiting for Godot. London, Great Britain: Faber and Faber.

[8] Belsey, Catherine. (1980). Critical Practice. London, Great Britain: Routledge.

[9] Bloom, Harold. (ed.), Samuel Beckett: Modern Critical Views. New York, USA: Chelsea House Publishers. 
[10] Chatterjee, Abhinaba. (2013). Camus' Absurdity in Beckett's Play: Waiting for Godot in Lapis Lazuli: An international literary journal (LLILJ), Vol. 3/No.2/ autumn, pp.196-205.

[11] D. Noble. (Ed.), Critical Insights. (pp.75-93). California, USA: Salem Press.

[12] Diamond, Elin. (2000). Re: Blau, Butler, Beckett, and Politics of Seeing In the Drama Review, 44, 4, pp. 31-34, New York, USA: University of Technology.

[13] Eagleton, Terry. (2003). Sweet Violence. London, Great Britain: Blackwell Publishing.

[14] Esslin, Martin. (1980). the Theatre of the Absurd. New York, USA: The Penguin Books.

[15] Esslin, Martin. (1960). the Theatre of the Absurd in the Tulane Drama Review, Vol 4. No. 4. (May 1960).

[16] Esslin, Martin. (Ed.), (1980). Samuel Beckett: Twentieth Century Views. New Delhi, India: Prentice Hall.

[17] Haney, William S. (2001). Beckett out of His Mind: The Theatre of the Absurd. Studies in Literary Imagination. Georgia: Georgia State University. 34, 2, pp. 39-53.

[18] Hawkes, D. (1996). Ideology. London, Great Britain: Routledge.
[19] Hooti, Noorbakhsh, (2011). Samuel Beckett's Waiting for Godot: A Postmodernist Study in English Language and Literature Study, Vol. I, pp.40-48.

[20] Jameson, Fredric. (2007). Modernist Papers .London, Great Britain: Verso.

[21] Jani, Darsha. (2013). Futility, Hopelessness and Meaninglessness: Central Forces Leading towards Absurdity in Beckett's Waiting for Godot in Lapis Lazuli: An International Literary Journal (LLILJ), Vol. 3/No.2/ Autumn, 2013, pp.96-106.

[22] Macherey, Pierre. (1978). A Theory of Literary Production. Trans. Geoffrey Wall .London, Great Britain: Routledge \& Kegan Paul.

[23] Rakwal, Komal. (2013). Today's Fear of Being in Samuel Beckett's Waiting for Godot in Lapis Lazuli: An International Literary Journal (LLILJ), Vol. 3/No. 2. / Autumn, pp.107-114.

[24] Ruby, Cohn. (Ed.), (1987).Beckett: Waiting for Godot. London, Great Britain: Casebook Series Macmillan Education Ltd.

[25] Schwab, Gabriele. (1992). "On the Dialectic of Closing and Opening in Endgame". In Waiting for Godot \& Endgame. Ed. Steven Connor. London: Macmillan. 